\title{
Retraction Note: Identify and measure the degree of over-prevention behaviors in the post-COVID-19 era in China
}

Rongyang $\mathrm{Ma}^{1}$, Hong $\mathrm{Wu}^{1 *}$ and Zhaohua Deng ${ }^{2}$

Retraction Note to: BMC Public Health 21, 1743 (2021)

https://doi.org/10.1186/s12889-021-11823-4

The Editors have retracted this article because this study had not received any ethics approval.

None of the authors have responded to any correspondence from the editor/publisher about this retraction.

\section{Author details}

'School of Medicine and Health Management, Huazhong University of Science and Technology, No. 13 Hangkong Road, Qiaokou District, Wuhan 430030, China. ${ }^{2}$ School of Management, Huazhong University of Science and Technology, Wuhan, China.

Published online: 10 December 2021

The original article can be found online at https://doi.org/10.1186/s12889021-11823-4.

*Correspondence: hongwu@hust.edu.cn

1 School of Medicine and Health Management, Huazhong University of Science and Technology, No. 13 Hangkong Road, Qiaokou District, Wuhan 430030, China

Full list of author information is available at the end of the article

(c) BioMed Central 2021. Open Access This article is licensed under a Creative Commons Attribution 4.0 International License, which permits use, sharing, adaptation, distribution and reproduction in any medium or format, as long as you give appropriate credit to the original author(s) and the source, provide a link to the Creative Commons licence, and indicate if changes were made. The images or other third party material in this article are included in the article's Creative Commons licence, unless indicated otherwise in a credit line to the material. If material is not included in the article's Creative Commons licence and your intended use is not permitted by statutory regulation or exceeds the permitted use, you will need to obtain permission directly from the copyright holder. To view a copy of this licence, visit http://creativecommons.org/licenses/by/4.0/. The Creative Commons Public Domain Dedication waiver (http://creativecommons.org/publicdomain/zero/1.0/) applies to the data made available in this article, unless otherwise stated in a credit line to the data. 